\title{
Recent trends in the timing of first sex and marriage among young women in Ethiopia
}

\author{
Ayalu A. Reda, MSc, MA*1, 2, 3 and David Lindstrom, PhD1, 2 \\ ${ }^{1}$ Population Studies and Training Center (PSTC), Brown University, Providence, RI, USA \\ ${ }^{2}$ Department of Sociology, Brown University, Providence, RI, USA \\ ${ }^{3}$ Department of Biostatistics, School of Public Health, Brown University, RI, USA
}

\begin{abstract}
Ethiopia has been characterized by high population growth. Recent social and economic developments have the potential to alter reproductive patterns in the country. Some of these developments include sustained economic growth, urbanization, rapid growth in school enrollments, expansion of primary health care, and a rise in contraceptive access and use. In other national contexts, these developments have been associated with a gradual decoupling of the transition into sexual activity and marriage among young women. We investigate recent trends in the transition into first sex and marriage among three cohorts of Ethiopian women. Methods: Using data from the 2000, 2005, and 20II Ethiopia Demographic and Health Surveys (DHS) we estimate survival curves and discrete-time hazards models to examine recent trends in age at first sex and first marriage among women ages 20-29. Results: Across the three survey years the median age at first sex has remained relatively stable at 17 years, although the median age at marriage has increased from 17 to 18 years between the 2005 and 2011 surveys. Net of the effects of education and place of residence, there is evidence of a slight trend away from premarital first sex to sexual initiation in the context of marriage. However, among the most educated women and women living in urban areas (who are a small minority of women), there is a much greater tendency to initiate sexual activity outside of marriage compared to women with little schooling and women living in rural areas, and once they have begun sexual activity they tend to wait longer before they get married. We also find evidence in the most recent survey that women who have first sexual intercourse before marriage are delaying marriage more than was the case among earlier cohorts.
\end{abstract}

Keywords: Ethiopia; reproductive behavior; intercourse; marriage, Demographic and Health Surveys (DHS)

\section{Résumé}

L'Ethiopie a connu une forte croissance de population. Les récents développements économiques et sociaux peuvent potentiellement affecter les modèles de reproduction dans le pays. Certains de ces développements incluent une croissance économique soutenue, l'urbanisation, une croissance rapide des inscriptions scolaires, l'expansion des soins de santé primaire, et un meilleur accès et usage des moyens de contraception. Dans d'autres cas nationaux, ces développements ont été associés à un découplage progressif de l'activité sexuelle et du mariage chez les jeunes femmes. Nous nous sommes intéressés aux nouvelles tendances concernant l'âge du premier rapport sexuel et l'âge du mariage au sein de trois groupes de femmes éthiopiennes. Méthodes: En utilisant les données provenant des Etudes sanitaires et démographiques d'Ethiopie de 2000, 2005 et 201 I, nous avons estimé les courbes de survie, ainsi que les modèles de risque à temps discret dans le but d'examiner l'âge du premier rapport sexuel ainsi que l'âge du premier mariage chez les femmes âgées de 20 à 29 ans. Résultats: En considérant les trois années étudiées, l'âge médian du premier rapport sexuel est resté relativement stable, à 17 ans, alors que l'âge médian du mariage est passé de 17 à 18 ans entre les études de 2005 et 201 I. Sans tenir compte du niveau d'éducation et du lieu de résidence, Il existe une légère difference entre le premier rapport sexuel avant le mariage et le début de l'activité sexuelle au sein du mariage. Cependant, les femmes les plus éduquées et les femmes vivant dans les zones urbaines (ce qui représente une minorité de femmes), tendent beaucoup plus à initier leur activité sexuelle avant le mariage,

\footnotetext{
* Corresponding author: Population Studies and Training Center, and Department of Sociology 
comparées aux femmes peu éduquées ou vivant en zones rurales; et lorsqu'elles ont commencé leur activité sexuelle, elles attendent plus longtemps avant de se marier. Nous avons aussi trouvé dans une étude plus récente, que les femmes qui ont leur premier rapport sexuel avant le mariage, se marient plus tard que les femmes des groupes étudiés antérieurement.

Mots clé: Ethiopie; reproduction; rapports; Enquêtes mariage, démographiques et de santé (EDS)

\section{Introduction}

Recent socio-economic and policy changes in Ethiopia have the potential to change reproductive and demographic behaviors and outcomes in a direction that is beneficial for the health and wellbeing of the population (Habumuremyi and Zenawi, 2012). Among these changes are an expansion in primary health care service coverage to $92 \%$ of the population ( $\mathrm{MOH}, 20 \mathrm{II})$, a liberalization of abortion laws providing widespread access to safe and affordable abortion (Gebreselassie et al., 20I0), the achievement of near universal primary school enrollment (World Bank, 2013b), sustained economic growth, and a reduction in poverty from $44 \%$ to $29 \%$ of the population (World Bank, 2013a). Additionally, close to 40,000 community health workers promoting contraceptive use have been deployed throughout the country (Olson and Piller, 2013, Wakabi, 2008, Abt Associates, 2012). In the wake of these changes and efforts, current contraceptive use among married women has increased from 14\% in 2005 to $29 \%$ in 201 I. Over the same six years the total fertility rate has declined from 5.4 children in 2005 to 4.8 in 201 I (CSA, 2012, CSA and ORC Macro, 2006).

Worldwide, there has been a general trend of declining age at first sex and an increasing age at first marriage (Marston et al., 2009, Harwood-Lejeune, 200I, Kirk and Pillet, 1998, Morgan SP, 2003, Wilson, 200I, Demeny and McNicoll, 2006, Mensh BS et al., 2005). This trend is also present in subSaharan Africa, albeit at varying levels (Bongaarts, 2007) with teenage premarital sexual activity becoming a common phenomenon in many countries (Marston et al., 2009). The research literature identifies several factors behind the trend towards increased first sex outside of marriage and delayed marriage. These factors include increased access to health care and education, urbanization, and improved infant and child survival (Livi-Bacci $M$, 2012, Mahy M and Gupta N, 200I). In addition to these factors which affect the demand for children, family planning communication and improvements in contraceptive supply also influence reproductive behavior (Bongaarts et al., 2012).
Family planning policies and related laws can have a substantial impact on sexual and reproductive behavior. Promoting awareness of family planning and providing contraception empower women to plan and control their fertility behavior. National family planning campaigns have the capacity to influence the demand for contraceptives irrespective of a country's level of socio-economic development, reduce unwanted pregnancies, and improve women's status and well-being (Ravenholt and Chao, 1974, Cleland et al., 2006, Hernandez, 198I, Bogue and Tsui, 1979). The Matlab Family Planning program in Bangladesh is a prime example of how contraceptive use can be increased through supply side mechanisms (Bhatia et al., 1980, Phillips et al., 1982).

In this article we examine the impact of recent socio-economic changes on the transition into sexual activity and marriage among women who are coming of sexual age. We use three rounds of the Ethiopia Demographic and Health Survey (DHS) to analyze trends. Lindstrom et al. (2009) analyzed the 2000 and 2005 Ethiopia DHS and reported progressively reduced risks of entry into marriage and first birth among recent cohorts of women. They also observed a reduced risk of premarital intercourse (Lindstrom et al., 2009). However, their analysis does not include the 20II DHS data, and thus does not capture the potential impacts of the recent and dramatic rise in contraceptive supply and use.

\section{Literature review and theoretical framework}

Age at first sex and first marriage has important implications for gender relations and the organization of family life in societies (Mensh BS et al., 2005, Malhotra, 1991, Short and Kiros, 2002). Studies in developed countries have found that the widespread availability of contraception is associated with a gradual decoupling of sexual debut and entry into marriage among women (Zelnik and Kantner, 1977, Waite LJ, 2006). When contraceptives are widely available, sexual intercourse tends to occur early, whereas marriage is delayed - leaving 
prolonged periods for sexual experimentation and mate selection (Goldin and Katz, 2000).

In sub-Saharan African countries, there is a wide range in age at first sexual intercourse as well as age at first marriage. The variation in the timing of first sex has been attributed to diverse environmental and social factors such as access to family planning programs, culture, and the prevalence of HIV/AIDs (Wellings et al., 2006). In general, there is an overall trend of increasing age at first marriage (Wellings et al., 2006, Dixon-Mueller, 2008). Most evidence indicates that delayed marriage is associated with changes in women's status, especially increased school enrollment and employment opportunities (Kaufmann and Meekers, 1998).

In many countries, delayed marriage has been associated with an increase in premarital sexual intercourse, but the evidence is far from uniform. For instance Zaba et al. report a consistent rise in age at first sex as well as a decline in premarital sex in Uganda, Ghana and Kenya (Zaba B et al., 2002). Mensch et al. have also reported that age at first sex has remained the same or increased in many African countries (Mensch et al., 2006). Similarly, Blanc and Way find that in many sub-Saharan African countries both age at first sex and age at marriage have increased and that the gap between the timing of the two events has increased primarily due to a longer delay in first marriage than in first sex (Blanc and Way, 1998).

\section{The Ethiopian context}

In Ethiopia the ages at first sexual intercourse and first marriage have been relatively low and closely concurrent. For instance, in the 1990s the national median age at first marriage for women aged 25-49 was 15.7 (Gebreselassie, 20II). Child marriage, defined as marriage below age 18 , continues to be a social and public health problem (Erulkar AS and Muthengi E, 2009, Erulkar, 2013). In an effort to reduce the prevalence of child marriage, the Ethiopian government in 2000 raised the legal minimum age at marriage to 18 years (Hailemariam A et al., 2006). Nevertheless, enforcement of the law is difficult and requires the cooperation of local community and religious authorities, especially in areas where marriages are formalized through traditional practices and not through legal registration. In addition to taking action to increase the age at marriage, the Ethiopian government has established very ambitious contraceptive prevalence and fertility reduction targets, and has implemented a number of national campaigns to meet those targets. In 1993 the government set a target of raising contraceptive prevalence from $4 \%$ of women of reproductive age to $44 \%$ by 2015 , and a target of reducing the total fertility rate from 7.7 to 4.0 children per woman over the same period. Fertility began declining in the 1990s, with the earliest and largest drops occurring in urban areas, giving signs of a fertility transition in progress with the total fertility rate (TFR) declining from 6.4 in 1990 to 4.8 in 201 I (Lindstrom and Berhanu B, 1999, CSA and ORC Macro, 2006, CSA and ORC Macro, 20I2). After 2000 , the demographic transition showed signs of stalling as in other African populations (Gebreselassie, 20I I, Teller et al., 20I I). In the mid2000s total fertility was 5.4, barely different from its level of 5.5 in 2000 (Gebreselassie, 20I I). However, the 20I I DHS survey indicates that fertility decline is again underway.

\section{Data and methods}

The Demographic and Health Surveys in Ethiopia provide nationally representative estimates of sexual and reproductive health. The surveys used sampling frames derived from the Population and Housing Censuses conducted by the Central Statistical Authority (CSA) of Ethiopia. Subdivisions of kebeles (the smallest administrative units in Ethiopia) were used as primary sampling units, and households comprised secondary sampling units. All women in the age range of 15 to 49 who were the usual residents of the sampled households or were guests who slept in the residence the night prior to the survey were interviewed. In this study we restrict our analytical sample to women ages 20-29 years at the time of the survey. This age restriction increases the sensitivity of our trend analysis to recent changes in behavior, and reduces potential problems with recall.

We use questions on age at first sexual intercourse and age at first marriage to define the outcomes: (I) first sex before marriage, (2) first sex at the same age as first marriage, and (3) marriage after first sex. In the DHS age at first sex is recorded in years or with the response 'first time when started living with (first) husband/partner.' Throughout this article, we use the term marriage to refer to first union. In the Ethiopian context first unions that are not formalized through a marriage ceremony or legal registration are generally recognized as marriages. In our analysis, we define premarital sex as first sex among never married women or first sex at a reported age that is less than the reported age at first marriage. We define first sex at the same age as first marriage as first sex that is reported at an age equal to the age at first 
marriage or the response 'first time when started living with (first) husband/partner.' Our definition of first sex at the same age as first marriage treats first sex that actually occurs before entry into a formal union but at the same age as occurring within the context of marriage because it is highly likely that it occurred in anticipation of a planned or ensuing marriage.

Using the person-level data from the three surveys we constructed a person-year file in which each record corresponds to a life year of exposure to the risk of first sex and first marriage. Exposure begins at age 10 and continues until first sex or first marriage occurs. For women who have first sex before marriage, we begin the risk period for the transition into marriage after premarital sex with the life year immediately following the year in which first sex occurs. Women who do not experience first sex or first marriage by the time of the survey are right censored in the year of the survey.

We begin with a descriptive analysis of the outcome variables and key background characteristics, including the estimation of KaplanMeier survival curves to show trends in the age patterns of first sex (irrespective of whether it is premarital or within the context of marriage) and first marriage. We then use discrete-time multinomial and binary logistic regression models to analyze the transitions into first premarital sex, first sex and first marriage at the same age, and first marriage among women who have premarital sex (Graham SE et al., 2012, Heeringa SG et al., 20I0). We apply sample weights to the survey data for our descriptive and multivariate analyses, and we adjust for clustering effects at the smallest geographic level associated with the survey design in the multivariate models.

The multivariate models include as independent variables education, place of residence, ethnicity and religion. We treat place of residence, ethnicity, and religion as time-invariant and reflective of women's status at the age in which exposure to the risk of first sex and first marriage begins. The assumption of time-invariance is most problematic for place of residence because of migration. However, we use a simple rural/urban dichotomy to define place of residence. Approximately $80 \%$ of the population lives in rural areas. Most migration in Ethiopia is rural-rural or urban-urban, and for women migration most often occurs in the context of marriage and the establishment of a new household (Djamba, 2003). We treat education as a timevarying variable for women who have secondary education or more and assign these women primary education in life years 10 through 15, and secondary education in life years beyond age 15 .

Religion is reported as Muslim, Protestant, Orthodox Christian, Catholic, other and traditional faiths. In the analysis we categorized Protestant, Orthodox Christian and Catholic into Christian, and other and traditional religion into other. Prior studies in Ethiopia find no significant differences in reproductive behavior between Christian groups (Korra, 2002), although Christian-Muslim differences are significant. In Ethiopia, there is considerable religious diversity across and within ethnic groups. We treat the second largest ethnic group, the Amhara, as the reference category for ethnicity, and we define dummy variables for the six other largest ethnic groups (Oromo, Tigray, Somali, Guraghe, Sidama, and Welaita) and group together into one "other" category smaller ethnic groups. In addition to ethnic variation, the ethnicity variables capture to some extent regional variation in patterns of age at first sex and first marriage due to the definition of regional boundaries in rough accordance with the spatial distribution of major ethnic groups.

Woman's education is reported in four categories: no education, primary, secondary and tertiary education. In Ethiopia, primary education involves the first eight years of study excluding preschool and kindergarten. Secondary school involves four years of study beyond primary school. Since the proportion of women with tertiary education was low, we group tertiary education with secondary or more.

The 2000 DHS included 5,443 women ages 2029, the 2005 included 5,002, and the 2011 included 5,895 . The response rates for the DHS in Ethiopia are exceptionally high with $97.8 \%$ of sampled women responding in $2000,95.6 \%$ in 2005 , and $95.0 \%$ in 2011 . Studies investigating the quality of the DHS data report the quality to be good (Mei Z and Grummer-Strawn LM., 2007, Mishra et al., 2006). Despite efforts to give participants some level of privacy, the collection of data through face-toface interviews, nevertheless, is likely to result in some under-reporting of sexual activity due to the sensitivity of questions about sexual behavior in the Ethiopian context, especially in rural areas (Curtis and Sutherland, 2004, Lindstrom et al., 2010, Lindstrom et al., 2012). There have been reports of problems with age rounding by respondents especially for children (Marckwardt AM and Rutstein SO., 1996). However, recall bias and age rounding is less problematic among younger compared to older 
respondents. The DHS questionnaires and data sets provide a way to identify inconsistencies in reports of the timing of first sex and first marriage by comparing responses on the date of birth, age, and calendar time of events, and questions that are repeated in different sections of the questionnaire. Using these multiple data points, the DHS data sets include separate variables that flag inconsistent responses. To reduce potential bias in our analyses we excluded inconsistent responses from the data set (roughly $3 \%$ ). Because the time span covered by the three survey years is only eleven years, the direction and magnitude of reporting errors and response bias is unlikely to vary significantly across survey years, and therefore should have minimal impact on our trend analysis.

\section{Results}

Women's level of education rose substantially across the three surveys and especially from 2005 to $201 \mathrm{I}$. The percentages of young women with no formal education declined from $70 \%$ in 2000 to $49 \%$ in $20 \mathrm{II}$, and the percentages of women with some schooling beyond the primary level increased from $13 \%$ to $16 \%$ over the same period. The relative proportion of women living in urban areas also increased between the second and third surveys, with 19\% of women ages $20-29$ living in urban areas in 2000 and 2005 , and $26 \%$ living in urban areas in 2011. Coinciding with the rise in women's education and the movement into urban areas is a dramatic rise in contraceptive use among currently married women. The 2000 DHS found that roughly $7 \%$ of currently married women ages $20-29$ were using a modern contraceptive method; by $20 \mathrm{II}$ the level had risen to $31 \%$. However, in contrast to the sharp and steady rise in contraceptive use among young married women, current contraceptive use among young unmarried women who had initiated sexual activity remained flat at around $18-20 \%$ across the three survey years.

By ages $20-29$ roughly $82-83 \%$ of Ethiopian women had first sexual intercourse and the median age at first sex is approximately 17 years. This age pattern of first sex has not changed across the three surveys. The proportion of married women is also similar across all three surveys at around $80 \%$. However, the median age at first marriage, which was 17 in the 2000 and 2005 surveys, increased to 18 years in the 2011 survey. Figure I presents Kaplan-Meier survival curves for age at first sex and age at first marriage. The two sets of survival curves follow one-another very closely indicating the tight coupling of the transitions into sexual activity and marriage. However, in both sets of curves, the curves corresponding to the $20 \mathrm{II}$ survey are slightly to the right of the curves for the 2000 and 2005 surveys. A log-rank test of the equality of the survival curves indicates that the shift to the right is only significant in the case of first marriage. The lack of any real change in the survival curves for age at first sex and the small rise in age at first marriage, are suggestive of the emergence of an age gap in the timing of first sex and first marriage among women who have first sex before marriage. 
Table I. Selected Life Course and Background Characteristics of Women Ages 20-29, Ethiopia DHS 2000, 2005 , and 2011 .

\begin{tabular}{|c|c|c|c|}
\hline \multirow[b]{2}{*}{ Life course and background characteristics } & \multicolumn{3}{|c|}{ Surveys } \\
\hline & DHS 2000 & DHS 2005 & DHS 2011 \\
\hline \multicolumn{4}{|l|}{ Education } \\
\hline No education & $70.2 \%$ & $64.4 \%$ & $49.0 \%$ \\
\hline Primary & $17.2 \%$ & $20.7 \%$ & $35.0 \%$ \\
\hline Secondary & $12.6 \%$ & $15.0 \%$ & $16.0 \%$ \\
\hline \multicolumn{4}{|l|}{ Place of residence } \\
\hline Rural & $80.7 \%$ & $80.8 \%$ & $73.4 \%$ \\
\hline Urban & $19.3 \%$ & $19.2 \%$ & $26.6 \%$ \\
\hline \multicolumn{4}{|l|}{ Current use of a modern contraceptive method among: } \\
\hline Currently married & $6.7 \%$ & $15.8 \%$ & $31.0 \%$ \\
\hline Never married and ever pre-marital sex & $19.5 \%$ & $19.6 \%$ & $17.7 \%$ \\
\hline Ever sex & $83.2 \%$ & $81.6 \%$ & $82.4 \%$ \\
\hline Ever married & $81.0 \%$ & $79.5 \%$ & $79.0 \%$ \\
\hline Ever pre-marital sex & $11.0 \%$ & $10.3 \%$ & $9.5 \%$ \\
\hline Ever pre-marital birth & $1.5 \%$ & $1.0 \%$ & $1.9 \%$ \\
\hline Median age at first sex & 17 & 17 & 17 \\
\hline Median age at first marriage & 17 & 17 & 18 \\
\hline Median time from premarital sex to first marriage (years) & 2 & 3 & 4 \\
\hline Number of women & 5,433 & 5,002 & 5,895 \\
\hline
\end{tabular}

Reported premarital first sex in Ethiopia is relatively uncommon, and there is evidence that the prevalence of premarital sex has remained relatively stable at around $10 \%$. Although it is highly likely that pre-marital sex is underreported in the survey, the very low levels of reported pre-marital births (I-2\% of women) are consistent with the reports of low levels of premarital sex, especially in the context of low levels of contraceptive use and limited access to abortion that characterized the period captured by the 2000 Ethiopia DHS. Among those women who have first sex before marriage the median time from first sex to marriage has increased across the survey years from 2 years in 2000, to 3 years in 2005 and 4 years in 201 I. The Kaplan-Meier survival curves for time from premarital sex to marriage shown in Figure $I(c)$ indicate that the increase in the waiting time from first sex to first marriage is greatest (and significant) for the 20I I DHS respondents. 
Figure I. Kaplan-Meier curves of transition to adulthood among 20-29 year old women in Ethiopia from the DHS 2000, 2005 and 20II

(a) Age at transition to first sex

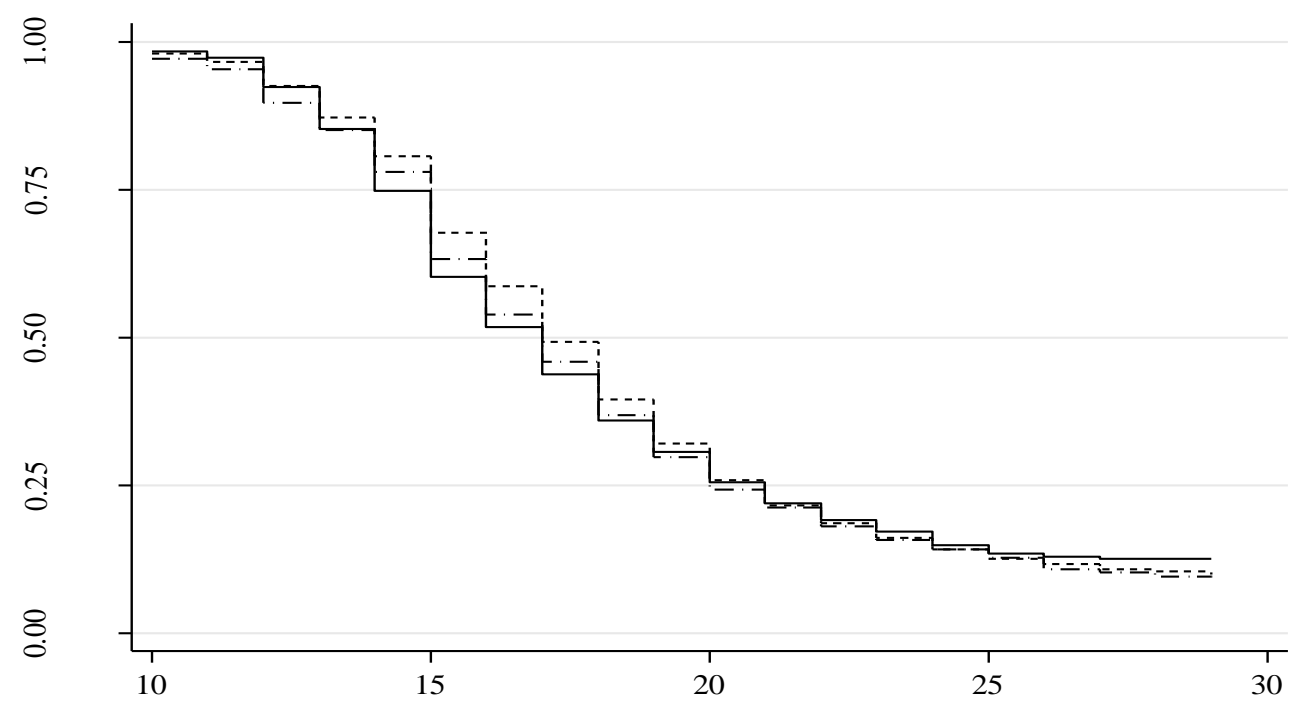

(b) Age at transition to first marriage

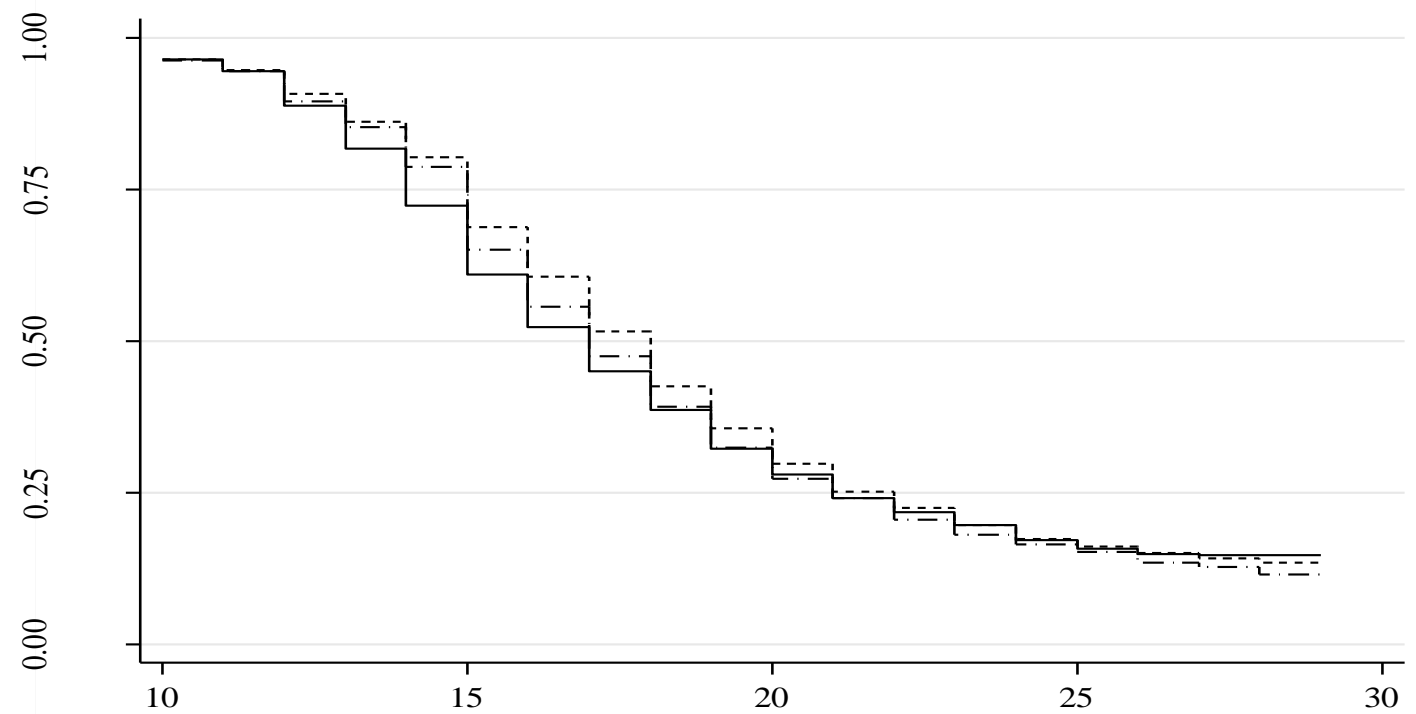

(c) Time taken to transition from premarital sex to first marriage 


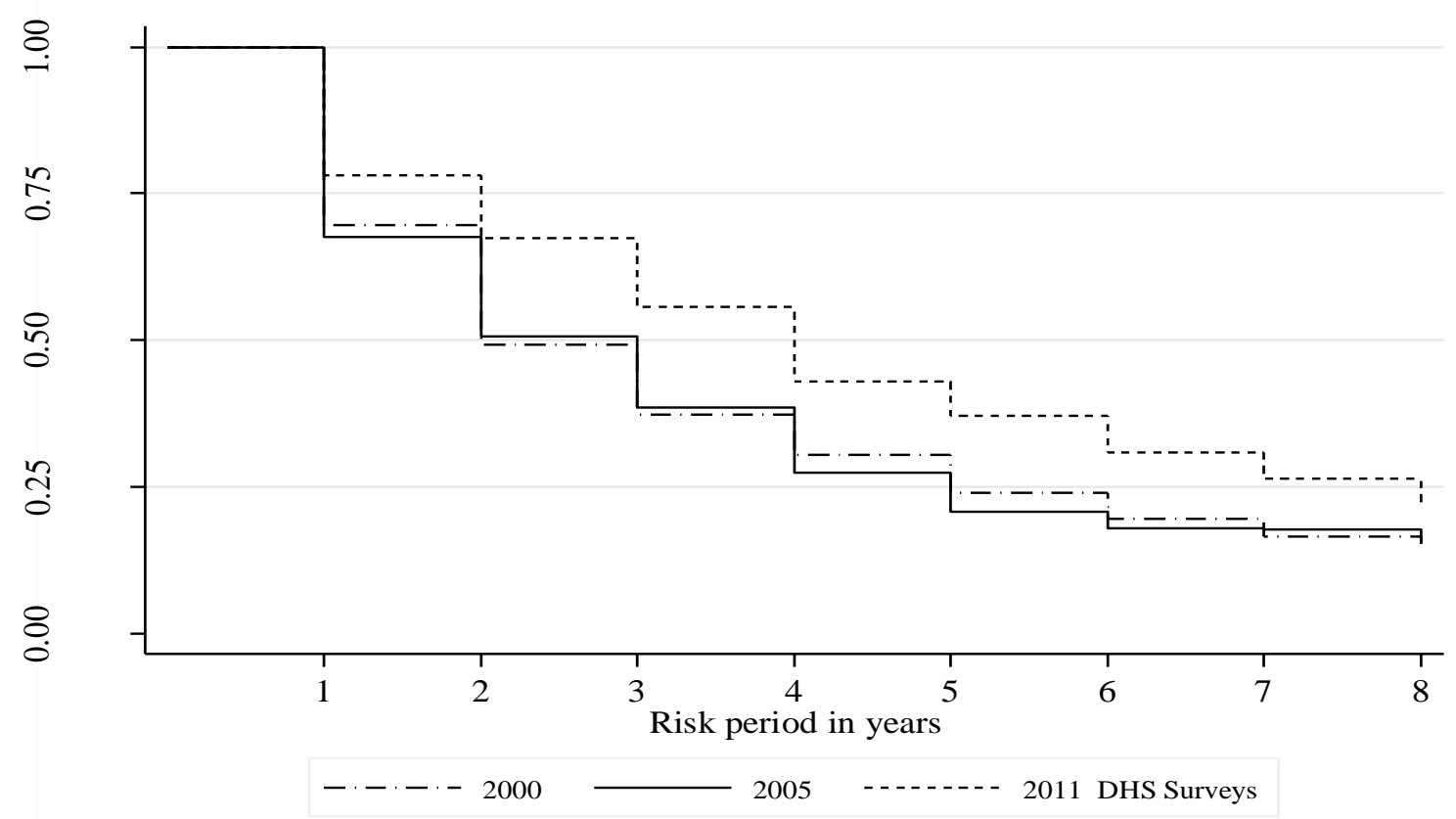

Predictors of the transitions into first sex and first marriage

The descriptive analysis reveals little change in age at first sex and a modest increase in age at first marriage - this is especially so for women who had premarital sex. The relative stability in age at first sex and first marriage occurs in the context of rapid growth in contraceptive access. Based on the experience of other populations that have also experienced increases in contraceptive access we might expect to see along with the delay in age at first marriage a rise in the prevalence of premarital sexual experience. More educated and urban women have often been at the forefront of change in sexual and marital behavior. In Ethiopia the vast majority of the population resides in rural areas and in spite of very impressive gains in primary education, the percentage of women who go onto secondary school and beyond remains relatively low and has changed at a more modest pace than the changes in contraceptive access and use. The relative stability in sexual and marital patterns among women at an aggregate level might mask new patterns of sexual and marital behavior among urban educated women because they are a relatively small proportion of the population. To examine differences by education and place of residence, and possible change over time in these group differences, we turn to discrete-time multinomial logistic regression models. 
Table 2. Odds Ratios from Discrete-time Multinomial and Binary Logistic Regression Models Predicting First Sexual Intercourse and Entry into Marriage among Women who had First Intercourse before Marriage, Women Ages 20-29, Ethiopia DHS 2000, 2005, 2011.

\begin{tabular}{|c|c|c|c|c|}
\hline \multirow[b]{2}{*}{ Predictor variables } & \multicolumn{3}{|c|}{ Multinomial model } & \multirow{2}{*}{$\begin{array}{c}\text { Binary model } \\
\text { Entry into marriage } \\
\text { among women who } \\
\text { had first intercourse } \\
\text { before marriage }\end{array}$} \\
\hline & $\begin{array}{c}\text { First intercourse at } \\
\text { time of marriage } \\
\text { VS } \\
\text { Not started } \\
\text { sexual activity }\end{array}$ & $\begin{array}{c}\text { First intercourse } \\
\text { before marriage } \\
\text { VS } \\
\text { Not started } \\
\text { sexual activity }\end{array}$ & $\begin{array}{l}\text { First intercourse } \\
\text { before marriage VS } \\
\text { At time of marriage }\end{array}$ & \\
\hline \multicolumn{5}{|l|}{ Education } \\
\hline No education (ref) & 1.00 & 1.00 & 1.00 & 1.00 \\
\hline Primary & $0.54^{* * *}$ & $0.72^{* * *}$ & $1.83^{* * *}$ & 0.91 \\
\hline Secondary & $0.22^{* * *}$ & 0.91 & $4.39^{* * *}$ & $0.53^{* * *}$ \\
\hline \multicolumn{5}{|l|}{ Residence } \\
\hline Rural & $1.54^{* * *}$ & $0.78^{*}$ & $0.65^{* * *}$ & $1.96^{* * *}$ \\
\hline \multicolumn{5}{|l|}{ DHS Survey } \\
\hline DHS 2000 (ref) & 1.00 & 1.00 & 1.00 & 1.00 \\
\hline DHS 2005 & 1.07 & 0.91 & 0.93 & 0.89 \\
\hline DHS 20II & $1.12^{*}$ & $0.79^{*}$ & $0.89^{*}$ & $0.80^{* *}$ \\
\hline \multicolumn{5}{|l|}{ Religion } \\
\hline Christian (ref) & 1.00 & 1.00 & 1.00 & 1.00 \\
\hline Moslem & $1.22^{* * *}$ & $0.54^{* * *}$ & $0.82^{* * *}$ & $1.62^{* * *}$ \\
\hline Other and traditional & 0.91 & 0.93 & 1.10 & 0.95 \\
\hline \multicolumn{5}{|l|}{ Ethnicity } \\
\hline Amhara (ref) & 1.00 & 1.00 & 1.00 & 1.00 \\
\hline Affar & $0.62^{* * *}$ & $0.40^{* *}$ & $1.6 \mathrm{I}^{* * *}$ & 1.06 \\
\hline Guragie & $0.32^{* * *}$ & $0.43^{* * *}$ & $3.10^{* * *}$ & 0.88 \\
\hline Oromo & $0.5 I^{* * *}$ & $0.50^{* * *}$ & $2.00^{* * *}$ & 1.05 \\
\hline Sidama & $0.62^{* * *}$ & $0.23^{* * *}$ & $1.60^{* * *}$ & 1.12 \\
\hline Somalie & $0.47^{* *}$ & $0.19^{* * *}$ & $2.11^{* * *}$ & $2.28^{*}$ \\
\hline Tigray & $0.77^{* * *}$ & 1.14 & $1.30^{* * *}$ & $1.38^{* *}$ \\
\hline Welaita & $0.44^{* * *}$ & $0.26^{* * *}$ & $2.27^{* * *}$ & 0.94 \\
\hline Others & $0.46^{* * *}$ & $0.26^{* * *}$ & $2.18^{* * *}$ & 1.14 \\
\hline Duration (years) & $3.90^{* * *}$ & $3.23^{* * *}$ & $0.26^{* * *}$ & $2.76^{* * *}$ \\
\hline Duration squared & $0.97^{* * *}$ & $0.97^{* * *}$ & $1.04^{* * *}$ & $0.91^{* * *}$ \\
\hline F-test & $89.91^{* * *}$ & & & \\
\hline Chi-squared LR & & & & $490.69^{* * *}$ \\
\hline Number of women & 16,330 & & & 2,149 \\
\hline Number of life years & 142,975 & & & 7,681 \\
\hline
\end{tabular}


We define three outcomes: first sex and first marriage at the same age, first sex before marriage, and not started sexual activity. Table 2 presents the odds ratios from the model predicting the risk of transition into marriage and first sex at each age. We begin the risk period for all women at age 10 . The odds ratios in the first column correspond to the risk of first sex and marriage at the same age versus not started sexual activity. The odds ratios in the second column correspond to the risk of first sex before marriage versus not started sexual activity, and the odds ratios in the third column compare the risk of first sex before marriage and first sex and marriage at the same age. The results for education provide clear evidence that higher education is associated with delayed entrance into both marriage and sexual activity. Young women with primary education are approximately one-half as likely to transition into first sex and first marriage at a given age as young women with no schooling, and women with a secondary education or above are one-fifth as likely to transition into first sex and first marriage as women with no schooling. Educated women are also less likely to transition into pre-marital sex at any age as women with no schooling, although the effect of education is only significant at the primary level. Even though women with education transition into sexual activity at older ages than women with no schooling, when they do become sexually active, educated women are significantly more likely to have first sex before marriage than women with no schooling. Women with primary education are 1.8 times as likely to have first sex before marriage compared to at the same age as marriage, as women with no schooling; and women with secondary education or above are 4.4 times as likely to have first sex before marriage compared to at the time of marriage as women with no schooling. Even after controlling for education, women living in rural areas are significantly more likely to transition into first sex and first marriage at the same age as women living in urban areas. On the other hand, rural women are significantly less likely than urban women to have first sex before marriage. After adjusting for education and place of residence, the odds ratios corresponding to survey year reveal a significant shift over time away from premarital sex and towards first sex and first marriage at the same age. This shift is present for both the 2005 and 201I survey respondents, but is only significant in $20 \mathrm{Il}$. The findings for religion are consistent with findings in other sub-Saharan countries. Moslem women are significantly less likely than Christian women to initiate sexual activity prior to marriage and are more likely to experience first sex in the context of entry into marriage.

Slightly more than one-in-ten of the women ages 20-29 in the three surveys had first sex before marriage. In the descriptive analysis we saw that the median time from first premarital sex to marriage increased significantly among women in the most recent 20II DHS. Table 2 presents the odds ratios from a discrete-time binary logistic regression model predicting the risk of first marriage among women who have had premarital sex. The multivariate results indicate that the transition from first sex to first marriage is slowest among women with secondary or higher education. In any given year these woman are at approximately one-half the risk of marriage as women with no schooling. On the other hand, women who live in rural areas and who start sexual activity before marriage are at approximately twice the risk of entry into marriage in any given year as urban women. Consistent with the Kaplan-Meier survival curves, the risk of transitioning from premarital sex into marriage at any given age declines across survey years, but the difference is only significant for the 20II DHS. Women age 20-29 who reported premarital sex in the $20 \mathrm{II}$ survey are at a $20 \%$ lower risk of getting married in any subsequent year as similarly aged women interviewed in the 2000 survey.

\section{Discussion and conclusions}

Overall our analysis indicates that the recent dramatic rise in contraceptive use in Ethiopia has not yet produced large changes at the national level in the timing and marital context of first sex among young women. We restricted our analysis to women ages 20-29 at the time of each survey to track recent change in behavior. However, the age restriction is not ideal for measuring very recent change since at least one-half of the women in each survey year would have experienced first sex and first marriage approximately 3-12 years prior to the year of the survey. A substantial proportion of the women interviewed in the 20II survey had already had first sex and entered into first marriage by the start of the 2005-20 II interval, during which the most impressive gains in contraceptive use were made. Nevertheless, we find evidence of a modest increase in the age at marriage that is due in part to a postponement of first sex among women who have premarital sex, followed by a postponement of marriage among these same women. A sharp increase in the proportion of women with a secondary level education, who tend to delay entry 
into first sex whether before marriage or in the context of marriage, has also contributed to a recent increase in the age at marriage.

Along with the modest increase in the median age at marriage there is evidence that recent cohorts of young women in Ethiopia are less likely to have first sexual intercourse outside of the context of marriage. There is also evidence that they have a slightly higher risk of transitioning into first sex and first marriage at any age compared to women interviewed in the 2000 DHS. Increased HIV awareness and knowledge of preventive behaviors may in part be responsible for this modest shift away from premarital sexual activity, although further analysis is needed to draw such a conclusion. Similar patterns have been observed in Kenya and Ghana (Zaba et al., 2004), and in Uganda, where the youngest cohort of women had a lower rate of premarital intercourse compared to earlier cohorts despite a delay in the age of marriage (Mensch et al., 2006, Slaymaker et al., 2009, Zaba et al., 2004). In a study of DHS data from southern and eastern Africa, Harwood-Lejeune also found that adolescent premarital sexual activity was declining (HarwoodLejeune, 200I). Even though the reason for the decline in pre-marital sexual activity is not known, it is hypothesized to be due to increased awareness of HIV infection risk and the subsequent abstinence as a preventive measure.

In Ethiopia, women with a secondary or higher level of education, and women living in urban areas, tend to marry at significantly older ages than their less educated and rural peers. They also tend to delay first premarital sexual intercourse if they have first sex before marriage. However, when educated and urban women do become sexually active, they are much more like to have premarital sex rather sex within the context of marriage than is the case for their less educated and rural peers. We also find that among women who have first sex before marriage, women with secondary or higher education, and women living in urban areas tend to wait longer until they get married. The pattern of sexual initiation before marriage and delayed marriage that is more common among highly educated and urban women in Ethiopia is broadly consistent with what has been observed among urban, educated women in many other diverse national contexts. Higher levels of education and urban living tend to be associated with a higher risk of premarital sex and a tendency to delay marriage, even after sexual activity has started. The widespread availability of modern contraceptive methods allows for a prolonged period of premarital sexual activity with a reduced risk of unwanted pregnancies. Because highly educated and urban women are such a small minority of the population in Ethiopia, recent trends in their behavior are not visible in aggregate trends which are heavily weighted by trends in the behavior of less educated and rural women. Nevertheless, urban educated women may serve as new models of reproductive and marital behavior that are diffused to other sectors of the population. If recent trends are an indicator of what is likely to come in Ethiopia, then we can expect at least in the near-term a gradual rise in both the age at marriage and the proportion of women who have first sex before marriage, but not necessarily a decline in the age at first sex.

\section{Author's contributions}

Both authors have contributed significantly to the manuscript. AAR analyzed the data and wrote the first draft of the manuscript. DL participated in the write up of subsequent drafts and provided feedback on data analysis.

\section{Authors Guarantee}

Both authors have contributed sufficiently to the article. The content of the article has never been published previously.

\section{Acknowledgement}

We would like to thank Kelley Smith, and Prof. Susan Short for their valuable feedback on the manuscript. We also thank Nathalie Oulhen for her work in translating the abstract into French. This work was supported by a grant from David and Lucile Packard Foundation.

\section{References}

ABT ASSOCIATES 2012. Health Extension Program:

An innovative solution to public health challenges of Ethiopia: A case study. In: 2020, H. S. (ed.). Bethesda, MD: Abt Associates.

BHATIA, S., MOSLEY, W. H., FARUQUE, A. S. \& CHAKRABORTY, J. 1980. The Matlab family planning-health services project. Studies in Family Planning, II , 202-2 I 2.

BLANC, A. K. \& WAY, A. A. 1998. Sexual behavior and contraceptive knowledge and use among adolescents in developing countries. Studies in Family Planning, 106-116.

BOGUE, D. J. \& TSUI, A. O. 1979. A Reply to Paul Demeny's" On the End of the Population Explosion". Popul Dev Rev, 5, 479-494. 
BONGAARTS, J. 2007. Late marriage and the HIV epidemic in sub-Saharan Africa. Popul Stud (Camb), 6I, 73-83.

BONGAARTS, J., CLELAND, J., TOWNSEND, J., BERTRAND, J. \& GUPTA, M. 2012. Family Planning Programs For the 2IST Century. New York: Population Council.

CLELAND, J., BERNSTEIN, S., EZEH, A., FAUNDES, A., GLASIER, A. \& INNIS, J. 2006. Family planning: the unfinished agenda. The Lancet, 368, I8I0-1827.

CSA 2012. Ethiopia demographic and health survey. In: CENTRAL STATISTICAL AUTHORITY OF ETHIOPIA (ed.). Addis Ababa, Ethiopia, and Calverton, USA: CSA, and ORC Measure Evaluation.

CSA \& ORC MACRO 2006. Ethiopian Demographic and Health Survey (DHS). In: CENTRAL STATISTICAL AUTHORITY AND ORC MACRO (ed.). Addis Ababa, Ethiopia and Calverton, USA: Central Statistical Authority,.

CSA \& ORC MACRO 2012. Ethiopia demographic and health survey 2011. Addis Ababa and Claverton,: Central Statistical Authority of Ethiopia,.

CURTIS, S. L. \& SUTHERLAND, E. G. 2004. Measuring sexual behaviour in the era of HIV/AIDS: the experience of Demographic and Health Surveys and similar enquiries. Sex Transm Infect, 80 Suppl 2, ii22-7.

DEMENY, P. \& MCNICOLL, G. 2006. The political demography of the world system, 2000-2050. Popul Dev Rev, 32, 254-287.

DIXON-MUELLER, R. 2008. How young is "too young"? Comparative perspectives on adolescent sexual, marital, and reproductive transitions. Studies in Family Planning, 39, 247-262.

DJAMBA, Y. K. 2003. Gender differences in motivations and intentions to move: Ethiopia and South Africa compared. Genus, 93-III .

ERULKAR, A. 2013. Early marriage, marital relations and intimate partner violence in Ethiopia. International Perspectives on Sexual and Reproductive Health, 39, 6-I3.

ERULKAR AS \& MUTHENGI E 2009. Evaluation of Berhane Hewan: A program to delay child marriage in rural Ethiopia. International Perspectives on Sexual and Reproductive Health, $35,6-14$.

GEBRESELASSIE, H., FETTERS, T., SINGH, S., ABDELLA, A., GEBREHIWOT, Y., TESFAYE, S., GERESSU, T. \& KUMBI, S. 20I0. Caring for women with abortion complications in Ethiopia: national estimates and future implications. International Perspectives on Sexual and Reproductive Health, 6-I5.

GEBRESELASSIE, T. 20II. The fertility transition in sub-Saharan Africa, 1990-2005: How uniqe is Ethiopia? In: TELLER C \& HAILEMARIAM A (eds.) The demographic transition in and development in Africa: The unique case of Ethiopia. New York: Springer.

GOLDIN, C. \& KATZ, L. F. 2000. The power of the pill: oral contraceptives and women's career and marriage decisions. National Bureau of Economic Research.

GRAHAM SE, WILLETT JB \& SINGER JD 2012. Using discrete-time survival analysis to study event occurrence. In: NEWSOM JT, JONES RN \& HOFER SM (eds.) Longitudinal data analysis: A practical guide for researchers in aging, health, and social sciences. Taylor \& Francis Group.

HABUMUREMYI, P. D. \& ZENAWI, M. 2012. Making family planning a national development priority. Lancet, 380, 78-80.

HAILEMARIAM A, MEKBIB T \& FANTAHUN M 2006. Family planning in Ethiopia. In: BERHANE Y, HAILE-MARIAM D \& KLOOS $\mathrm{H}$ (eds.) Epidemiology and ecology of health and disease in Ethiopia. Addis Ababa.

HARWOOD-LEJEUNE, A. 200I. Rising age at marriage and fertility in southern and Eastern Africa. European Journal of Population-Revue Europeenne De Demographie, 17, 26I-280.

HEERINGA SG, WEST BT \& BERGLUND PA 2010. Survival analysis of event history survey data. Applied survey data analysis. Boca Raton, FL: Taylor \& Francis Group.

HERNANDEZ, D. J. 198I. A note on measuring the independent impact of family planning programs on fertility declines. Demography, 18, 627-634.

KAUFMANN, G. \& MEEKERS, D. 1998. The impact of women's socioeconomic position on marriage patterns in sub-Saharan Africa. Journal of Comparative Family Studies, 29, I0I-I I4.

KIRK, D. \& PILLET, B. 1998. Fertility levels, trends, and differentials in sub-Saharan Africa in the 1980s and 1990s. Studies in Family Planning, 29, I-22.

KORRA, A. 2002. Attitudes toward family planning and reasons for nonuse among women with unmet need for family planning in Ethiopia. Calverton, MD, USA: ORC Macro. 
LINDSTROM, D. P., BELACHEW, T., HADLEY, C., HATTORI, M. K., HOGAN, D. \& TESSEMA, F. 2010. Nonmarital sex and condom knowledge among Ethiopian young people: improved estimates using a nonverbal response card. Studies in Family Planning, 4I, 25 I-262.

LINDSTROM, D. P. \& BERHANU B 1999. The impact of war, famine, and economic decline on marital fertility in Ethiopia. Demography, 36, 24761.

LINDSTROM, D. P., HATTORI, M. K., BELACHEW, T. \& TESSEMA, F. 20I2. Lifting the curtain on the conditions of sexual initiation among youth in Ethiopia. Journal of Adolescent Health, 50, 614-620.

LINDSTROM, D. P., KIROS, G.-E. \& HOGAN, D. P. 2009. Transition into first intercourse, marriage, and childbearing among Ethiopian women. Genus, 65.

LIVI-BACCI M 20I2. Demographic growth: Between choice and constraint. In: LIVI-BACCI $M$ (ed.) A concise history of world populaiton. 5th Edition ed.

MAHY $M$ \& GUPTA $N$ 200I. Trends and differentials in age at first birth in sub-Saharan Africa. XXIVth IUSSP General Population Conference. Slavador, Brazil.

MALHOTRA, A. 1991. Gender and changing generational relations: spouse choice in Indonesia. Demography, 28, 549-70.

MARCKWARDT AM \& RUTSTEIN SO. 1996. Accuracy of DHS-II demographic data: gains and losses in comparison with earlier surveys. DHS working papers. Calverton, MD: ORC Macro International.

MARSTON, M., SLAYMAKER, E., CREMIN, I., FLOYD, S., MCGRATH, N., KASAMBA, I., LUTALO, T., NYIRENDA, M., NDYANABO, A., MUPAMBIREYI, Z. \& ZABA, B. 2009. Trends in marriage and time spent single in sub-Saharan Africa: a comparative analysis of six populationbased cohort studies and nine Demographic and Health Surveys. Sex Transm Infect, 85 Suppl I, i64-7I.

MEI Z \& GRUMMER-STRAWN LM. 2007. Standard deviation of anthropometric Z-scores as a data quality assessment tool using the $2006 \mathrm{WHO}$ growth standards: a cross country analysis. Bull World Health Organ, 85, 44I-448.

MENSCH, B., GRANT, M. \& BLANC, A. 2006. The Changing Context of Sexual Initiation in subSaharan Africa. Popul Dev Rev, 32, 699-727.
MENSH BS, SINGH S \& CASTERLINE JB 2005. Trends in the timing of first marriage among mena and women in the developing world. Working paper. New York: Population Council: Policy research division.

MISHRA, V., VAESSEN, M., BOERMA, J. T., ARNOLD, F., WAY, A., BARRERE, B., CROSS, A., HONG, R. \& SANGHA, J. 2006. HIV testing in national population-based surveys: experience from the Demographic and Health Surveys. Bull World Health Organ, 84, 537-45.

$\mathrm{MOH} 20 \mathrm{II}$. Health and health related indicators. In: POLICY AND PLANNING DIRECTORATE (ed.). Addis Ababa: Federal Democratic Republic of Ethiopia,.

MORGAN SP 2003. Is low fertility a twenty-firstcentury demographic crisis? Demography, 40, 589-603.

OLSON, D. J. \& PILLER, A. 2013. Ethiopia: An Emerging Family Planning Success Story. Studies in Family Planning, 44, 445-459.

PHILLIPS, J. F., STINSON, W. S., BHATIA, S., RAHMAN, M. \& CHAKRABORTY, J. 1982. The Demographic Impact of the Family Planning-Health Services Project in Matlab, Bangladesh. Studies in Family Planning, I $3 \mathrm{I}-140$.

RAVENHOLT, R. T. \& CHAO, J. 1974. Availability of family planning services the key to rapid fertility reduction. Family Planning Perspectives, 6, 217-223.

SHORT, S. E. \& KIROS, G.-E. 2002. Husbands, wives, sons, and daughters: Fertility preferences and the demand for contraception in Ethiopia. Population Research and Policy Review, 21, 377402.

SLAYMAKER, E., BWANIKA, J. B., KASAMBA, I., LUTALO, T., MAHER, D. \& TODD, J. 2009. Trends in age at first sex in Uganda: evidence from Demographic and Health Survey data and longitudinal cohorts in Masaka and Rakai. Sex Transm Infect, 85, il 2-il 9.

TELLER, C. H., HAILEMARIAM, A., GEBRESELASSIE, T. \& SEIFU, Y. 20II. The uniqueness of the Ethiopian demographic transition within sub-Saharan Africa: multiple responses to population pressure, and preconditions for rural fertility decline and capturing the demographic dividend. African Population Studies, 25, 362-380.

WAITE LJ 2006. Marriage and family. In: POSTON DL \& MICKLIN M (eds.) Handbook of Population. New York: Springer. 
WAKABI, W. 2008. Extension workers drive Ethiopia's primary health care. Lancet, 372, 880.

WELLINGS, K., COLLUMBIEN, M., SLAYMAKER, E., SINGH, S., HODGES, Z., PATEL, D. \& BAJOS, N. 2006. Sexual behaviour in context: a global perspective. The Lancet, 368, I706- 1728.

WILSON, C. 200I. On the scale of global demographic convergence, 1950-2000. Popul Dev Rev, 27, |55-7|.

WORLD BANK. 2013a. Ethiopia at a glance [Online]. Washington D.C.: WB. Available: http://devdata.worldbank.org/AAG/eth_aag.pdf [Accessed March 3I 20I3].

WORLD BANK. 20I3b. World Development indicators: Ethiopia [Online]. Washington D.C.: The World Bank. Available: http://data.worldbank.org/country/ethiopia [Accessed April 02 20I3].
ZABA B, BOERMA T, PISANI E \& BAPTIESTE N. 2002. Estimation of levels and trends in age at first sex from surveys using survival analysis. Working Papers [Online].

ZABA, B., PISANI, E., SLAYMAKER, E. \& BOERMA, J. T. 2004. Age at first sex: understanding recent trends in African demographic surveys. Sex Transm Infect, 80, ii28-ii35.

ZELNIK, M. \& KANTNER, J. F. 1977. Sexual and contraceptive experience of young unmarried women in the United States, 1976 and 197I. Family Planning Perspectives, 9, 55-7I. 